\title{
INTERRELATION OF BIOLOGICAL RHYTHMS AND CIRCADIAN HORMONES PRODUCEMENT AND THEIR IMPACT ON MEDICINE USAGE
}

\author{
Maryna Y. Vasko, Iryna M. Tkachenko, Olena V. Pavlenkova, Oleg A. Pysarenko \\ POLTAVA STATE MEDICAL UNIVERSITY, POLTAVA, UKRAINE
}

\begin{abstract}
The aim of the article is to establish the interrelation of human biological rhythms and circadian hormones producement as well as to determine their impact on the medicine usage. Materials and methods: The review and latest data analysis of scientific and medical literature were performed.

Conclusions: Proceeding from the literature sources there is a firm interrelation between human biological rhythms and circadian hormones producement. Following chronotherapy principles will allow to increase effectiveness of diseases treatment, including dental ones. It will also allow to reduce dosage of prescribed medicines as well as their side effects. Prospects for a further research are to identify a clear relationship between circadian biorhythms in patients with chronic generalized periodontitis in order to increase the effectiveness of therapeutic measures.
\end{abstract}

KEY WORDS: circadian biorhythm, chronotype, chronotherapy, desynchrony

\section{INTRODUCTION}

Biorhythms are the periodically recurring changes in the nature and intensity of biological processes and phenomena [1]. The formation of biological rhythms is inextricably linked with the evolutionary process that has been occurring from the very beginning of the origin and formation of life in the development of environmental spatio-temporal patterns of the environment [2]. Due to biorhythms physiological functions of the body are coordinated with the rhythms of the environment.

Biorhythms have a fundamental role in the homeostasis coordination and biological systems behavior, provide internal movement, development of human organism and its functional systems [3-8].

Coordinated work of the abovementioned systems as well as their interconnected adaptation mechanisms is possible only in the rhythmic organization of physiological processes condition. Understanding the basic circadian functions has led to important medical archievements in chronotherapy, namely taking medicines at certain times of the day in order to increase the effectiveness of treatment of numerous systemic diseases and reduce drug toxicity $[5,9]$.

\section{THE AIM}

The aim of this research is to establish interrelations of human biological rhythms with the circadian hormones producement and to clarify their impact on the medicines usage.

\section{MATERIALS AND METHODS}

The review and latest data analysis of scientific and medical literature were performed.

\section{REVIEW AND DISCUSSION}

In a human body there are about 500 biorhythms at different structural levels: cellular, tissue, organ, organismic. In a complex system of biorhythms: from the short ones which are at the molecular level with a few seconds periodicity to the global ones which are associated with annual changes in solar activity, the important role is taken by circadian rhythms with a 24 hours frequency dependent on Earth rotation around its axis and day-night periodicity. These endogenous rhythms are triggered by mechanisms which are called biological clocks. The dynamics of daily biorhythms parameters is called chronotype. It is referred to the behavioral patterns or manifestations based on biological processes controlled by circadian rhythms [10-14].

The tradition to divide people by the type of their peak of activity on "owls" (evening peak) and "larks" (morning peak) arose in 1939. This terminology came from the physiotherapist G. Lampert. Starting from the second half of XX century there is a growing interest in research of chronobiology domain. In 1959, Halberg called "circadian rhythms" biological rhythms with a period of about 24 hours [15].

Modern chronobiology reveals the nature of what is formulated by its axiom - "the organism is not identical 
to itself at different points in time." By the end of the XX century the fact of rhythmic biological processes of living organisms was rightly considered as one of the fundamental properties of a living organism $[2,11]$.

Nowadays, the majority of scientists support the multi-oscillatory concept of regulation of the circulatory system of mammals with a central oscillator in the suprachiasmatic nucleuses of hypothalamus (CNS) - «the master clock» and the main humoral modulator - pineal gland, which performs its chronobiotic function by melatonin which is a "sleep hormone" $[6,7,16-22]$. The physiological significance of melatonin is manifested in the synchronization of different biological processes according to day- and night-time illumination as well as during season changes. The hypothalamus generates an endogenous circadian rhythm with a period of 23-25 hours and the external "light-darkness" rhythm which has 24 hours periodicity and regulates endogenous rhythms in relation to the rhythms of the environment. The circadian rhythm driver responds to various light parameters such as wavelength and duration of light exposure time. [1, 3, 12, 23-27].

Discordance of circadian rhythm (desynchronosis) is one of the factors in pathological processes development. Desynchrony is considered as a predictor of a disease and is manifested by autonomic, immune, endocrine cardiovascular, respiratory, digestive and other functional systems disorders different in nature and severity [28-31].

Any inconsistencies in biorhythms lead to pathology, if exceed the homeostatic capacity i.e. possible biorhythms periodicity deviations without stability violation $[1,12$, $23,24,32,33]$.

More and more scientists confirm that biological rhythms should be considered when prescribing any treatment. As the sensitivity and tolerance of the organism to chemicals can vary significantly depending on the time of day [34].

Chronotherapy seeks to find a circadian stage when a medicine will be the most effective. Circadian rhythms fluctuate throughout the day and any two people with equal rhythms doesn 't exist, thus, therapy should be more individualized. The choice of medication time, prescriptions of special forms with prolonged or delayed action may not only enhance the effect, but also reduce the dose, mitigate or eliminate side effects, which is especially important in treatment optimization [35-38]. 75\% of chronomedical clinical studies (78 out of 105) published in recent 50 years report about diurnal dependence of treatment such diseases as allergies, asthma [24, 27, 39]. Circadian regulation of medicines metabolism has been used to treat diabetes, hypertension, peptic ulcer disease and allergic rhinitis for many years [40].

At chronotherapy an imitative, preventive (prophylactic) methods of medicines application are used. Also, method of a rhythm "obtrusion" is used. The imitative method is used with application of corticosteroids as it was found that minimal changes in the function of the adrenal cortex are observed when prescribing these medicines only in combination with the natural circadian rhythm of their secretion and excretion. If glucocorticoids are used outside the acrophase (in the evening and at night hours), it leads to their catabolic effect increasement as well as to decrease in body weight and adrenal mass. [12, 24].

In case of treatment with corticosteroids an opposite direction of action of cortisol and aldosterone in the organism should be taken into consideration. Thereby, mineralocorticoids (pro-inflammatory hormones) activity may be suppressed by the administration of an appropriate dose of glucocorticoids in the afternoon. Glucocorticoids are prescribed in the morning (6-7 a.m.) at replacement therapy. Thus, the circadian rhythm of cortisol synthesis is simulated and the time of its greatest need in human organism is counted. [12, 24].

It is known that histamine is synthesized by histidine decarboxylase in the evening and is degraded in the presence of diamine oxidase (histaminase) in the morning while its highest activity is observed in the evening and at night hours. Maximal concentration of histamine in the blood is determined from 9 p.m. to midnight. Therefore, the organism sensitivity to histamine increases during the period of glucocorticoids level decrease and reduces during the period of mineralocorticoids and acetylcholine concentration increasement. The circadian rhythm of histamine changes in human organism indicates the need for antihistamines in the afternoon and evening (at $3-4$ p.m. and 7-9 p.m.) $[12,24]$.

Analgesics are more effective in the afternoon. For example, the maximal analgesic effect of lidocaine in dental caries is observed if used at 2 p.m. while morphine's maximal effect is observed if injected at 9 p.m. [12, 24].

The presence of circadian rhythmic of arterial and venous pressure in both healthy people and people with arterial hypertension indicates the involvement of melatonin in the regulation of cardiovascular function. This statement is also supported by the presence of melatonin receptors in the intermuscular layer and vascular endothelium $[1,16,18,41]$.

A nocturnal decrease in blood pressure in healthy individuals within the range of $10-20 \%$ compared to daytime is observed. Patients with hypertension are characterized by a sharp arisement of blood pressure in early morning hours. The morning peak of blood pressure (increase of morning blood pressure magnitude and speed) is associated with the greatest number of cardiovascular complications, especially in the first two hours after awakening. One third of heart attacks occur immediately after awakening (highest risk is after 6 a.m.). Apoplexy and ventricular tachycardia are also more common in the morning [23, 24, 41-43].

Preventive chronotherapy patterns are used when prescribing antihypertensive medicines, anticoagulants, statins, when the drug is prescribed a few hours before the disease's acrophase onset [41]. I.e. in case of rheumatoid arthritis pain and stiffness in the joints usually peak early in the morning. Patients should take nonsteroidal anti-inflammatory medicines after supper. There are two advantages in this strategy. Firstly, it is considered to be 2 times more effective if you apply them at least 2 hours before the pain reaches its peak. Secondly, their side effects such as stomach irritation, headache, anxiety are significantly reduced at night [24]. 
In healthy children and adults bronchial patency is directly dependent on the glucocorticoid activity of adrenal cortex. In case of bronchial asthma bronchial resistance is minimal at midday and maximal from 11 p.m. to midnight, which is related to the increased sensitivity of the receptor apparatus of the bronchi to acetylcholine and histamine. Usually the peak of asthma attacks occurs at about 4 a.m. Researchers proved that lung function has the lowest level due to the coincidence of several circadian rhythms, including spasm of the smooth muscles of the bronchi exactly of that time.

Our own, anti-inflammatory and anti-asthmatic «drug» is a cortisol, the adrenal cortex hormone is produced in the organism in minimal amount after midnight. The level of adrenaline, which optimizes breathing, also decreases at night. At the same time, sensitivity to allergens increases. It makes sense to choose long-acting anti-asthmatic drugs. Such drugs should be taken in evening and in 12 hours . Its effect reaches a maximum just before dawn [12, 24, 39, 44]. Chronic gastroduodenal pathologies (primarily peptic ulcer disease) are characterized by both daily and seasonal periodicity. Increased secretion and acidity of stomach acid is especially pronounced at night. Therefore, antacids should be prescribed during the day and always before going to bed while antisecretory medicines (M-cholinolytics, blockers of histamine H2-receptors) - 1 time in the evening at 7-8 p.m. This contributes to a more effective stomach acid acidity reduction than consummation of 3 daily doses $[12,24]$.

Exacerbation of peptic ulcer in duodenum is most often observed in autumn and spring, while the highest rate of peptic ulcer disease aggravation is observed in summer. Patients with peptic ulcer disease have an increases of histamine, serotonin, insulin, cortisol secretion in the spring months and increases of gastrin, adrenaline, norepinephrine production in summer. These patients also have an increased activity of acetylcholinesterase which limits cortisol formation as well as histamine, serotonin, adrenaline, norepinephrine synthesis and decrease of acetylcholinesterase activity.

Thus, a pronounced tension of regulatory mechanisms is observed in spring while in autumn their suppression is detected. Based on these data, we can conclude that the usage of histamine $\mathrm{H} 2$-receptor blockers (cimetidine, famotidine, ranitidine, etc.) 1 time per night, and prescription of $\mathrm{M}$-cholinoreceptor blockers (gastroceptin, etc.) 1 time per night in autumn is pathogenetically justified for prevention of peptic ulcer disease exacerbations in spring and autumn $[12,24]$.

The «method of rhythms imposition» supposes blockage of pathological rhythms (desynchronosis) that have formed during the disease, as well as to impose rhythms that approach to physiological ones. This method is the basis of the pulse therapy (introduction of glucocorticoids and cytostatics in large doses at certain intervals). Recently, pulse therapy has been finding the growing widths of applications, especially in the treatment of severe forms of diffuse connective tissue diseases, systemic vasculitis and other immunopathological diseases [24].
One of the possible mechanisms of daily fluctuations in carbohydrate metabolism in healthy and people with diseases may be the circadian rhythm of peripheral insulin reception changes $[1,45,46]$. It is known that cyclic sensitivity to exogenous insulin depends on the food intake rhythm, the state of intestinal absorption, biorhythms of enzymatic activity of the organism and a number of other factors.

It was proved by the number of experimental studies that the blood level of glucose does not change significantly in healthy people during the day, while in patients with diabetes some diurnal rises and falls in blood glucose levels were mentioned considering the chronobiological rhythm and diet.. Diurnal and seasonal carbohydrate balance depends on the interaction of insulin and contrainsular hormones. The most important of the last ones are glucocorticoids, catecholamines, glucagon, somatotropic hormone, thyroid hormones. Each of them has its own circadian rhythms of secretion with acrophases, which cover almost all day [1].

It is known that single consommation of hydrocortisone "per os" in $100 \mathrm{mg}$ dose by healthy people is followed by a rapid decrease in insulin secretion without any change in blood glucose. Though, insulin rate has been growing for 4-6 hours remained elevated for 16 years. Diurnal changes of glucose tolerance is conditioned by the so-called phenomenon of «morning star» (dawn phenomenon), which suppose in glucose levels increase in blood in the early morning hours. The mechanism of the "dawn star" phenomenon development which is appropriate for both healthy people and diabetics is considered to be the influence of a number of hormonal contrainsular hormones (somatotropic hormone, cortisol, etc.), the acrophase of secretion of which occurs at daytime. Healthy people are characterized by individual daily tissue sensitivity to insulin. It was found that the need for insulin per unit of glucose increases during the day and decreases in the evening and at night $[1,47]$.

In patients with chronic generalized periodontitis, exacerbations are most often observed in autumn and spring. This may be related to the seasonal frequency of concomitant somatic pathology. However, the scientifically confirmed subordination to the circadian rhythm of all biological processes in organism suggests that generalized periodontitis has a daily dependence. Chronic generalized periodontitis is a multifactorial disease cccording to modern ideas. Considering such factor as the diurnal biorhythmological profile of a patient and the exact time of the acrophase of his daily rhythm will increase treatment of this pathology. Diurnal changes of dystrophic-inflammatory processes in periodontal tissues can be clearly traced in the immunological parameters. Collection and examination of buccal epithelium in patients may be a marker of diurnal changes that occur in periodontium.

Yui R.I. and Ergazina M.Zh. have developed a schema of preventive chronotherapy for patients with chronic generalized gingivitis and chronic generalized periodontitis in their study. They have proposed a pattern of preventive 
chronotherapy for patients with chronic generalized gingivitis and chronic generalized periodontitis, which would increase the effectiveness of medicines, reduce their toxic effects, accelerate the regeneration of gingival epithelium and reduce treatment time [48].

\section{CONCLUSIONS}

According to the literature sources, there is a clear relationship between human biological rhythms and the production of diurnal hormones. Considering the principles of chronotherapy will increase the effectiveness of diseases treatment, reduce the medicine dose and its side effects. Prospects for further research are to identify a clear relationship between circadian biorhythms in patients with chronic generalized periodontitis in order to increase the effectiveness of therapeutic measures.

\section{REFERENCES}

1. Hozhenko A.I., Hryshko Yu.M. Dobovi rytmy ta yikh dysbalans, yak odyn z mekhanizmiv porushennia zdorovia suchasnoi liudyny (ohliad literatury) [Circadian rhythms and their imbalance as one of the mechanisms of health disruption in modern people (review)]. Aktualni problemy transportnoi medytsyny: navkolyshnie seredovyshche; profesiine zdorov'ia; patolohiia. 2018;4(54):178-190. doi: 10.5281/ zenodo.2526928 (in Ukrainian).

2. Rapoport S.I., Chibisov S.M. Hronobiologija i hronomedicina: istorija i perspektivy [Chronobiology and chronomedicine: history and perspectives]. Hronobiologija i hronomedicina: monografija. Moskva: RUDN; 2018, 9-38. (in Ukrainian).

3. Agostinelli F, Ceglia N., Shahbaba B. et al. What time is it? Deep learning approaches for circadian rhythms. Bioinformatics. 2016;32(12):i8-i17. doi: 10.1093/bioinformatics/btw243.

4. Braun R., Kath W.L., Iwanaszko M. et al. Universal method for robust detection of circadian state from gene expression. Proc Natl Acad Sci USA. 2018;115(39):E9247-E9256.

5. Burish M.J., Chen Z., Yoo S.H. Emerging relevance of circadian rhythms in headaches and neuropathic pain. Acta Physiol (0xf). 2019;225(1):e13161. doi: 10.1111/apha.13161.

6. Deaver J.A., Eum S.Y., Toborek M. Circadian Disruption Changes Gut Microbiome Taxa and Functional Gene Composition. Front Microbiol. 2018;9:737. doi:10.3389/fmicb.2018.00737.

7. Johnston J.D., Ordovás J.M., Scheer F.A. et al. Circadian Rhythms, Metabolism, and Chrononutrition in Rodents and Humans. Adv Nutr. 2016;7(2):399-406. doi:10.3945/an.115.010777.

8. Takahashi J.S. Transcriptional architecture of the mammalian circadian clock. Nat Rev Genet. 2017;18(3):164-179.

9. Dong D., Yang D., Lin L. et al. Circadian rhythm in pharmacokinetics and its relevance to chronotherapy. Biochem Pharmacol. 2020;178:114045. doi: 10.1016/j.bcp.2020.114045.

10. Afanas'eva A.D. Bioritmyi ih vlijanie na adaptivnye vozmozhnosticheloveka [Biological rhythms and their impact on human adaptive abilities]. Bjulleten'medicinskih Internet-konferencii. 2016;6(5):653. (in Ukrainian).

11. Evdokimova E.M., Polujektov M.G., Tabeeva G.R. Hronobiologicheskie osobennosti golovnyh bolej i rol melatonina v reguljacii biologicheskih ritmov [Chronobiological features of primary headaches and the role of melatonin in the regulation of biological rhythms]. Medicinskij Sovet. 2019;(1):33-38. doi: 10.21518/2079-701X-2019-1-33-38 (in Ukrainian).
12. Neudahin E.V. Hronoterapija v pediatrii - osnova povyshenija jeffektivnosti lechenija zabolevanij u detej [Chronotherapy in pediatrics is the basis for improving the effectiveness of treatment of children`s diseases]. Ros Vestn Perinatol i Pediatr. 2018;63(6):7-14. doi 10.21508/1027-4065-2018-63-5-7-14 (in Ukrainian).

13. Kalmbach D.A., Schneider L.D., Cheung J. et al. Genetic Basis of Chronotype in Humans: Insights From Three Landmark GWAS. Sleep. 20171;40(2):zsw048. doi: 10.1093/sleep/zsw048.

14. Potter G.D., Skene D.J., Arendt J. et al. Circadian Rhythm and Sleep Disruption: Causes, Metabolic Consequences, and Countermeasures. Endocr Rev. 2016;37(6):584-608. doi: 10.1210/er.2016-1083.

15. Chi-Castañeda D., Ortega A. Glial Cells in the Genesis and Regulation of Circadian Rhythms. Front Physiol. 2018;9:88. doi:10.3389/fphys.2018. 00088.

16. Gubin D.G. Hronodiagnostika i hronoterapija - osnova personalizovannoj mediciny [Chronodiagnostics and chronotherapy - frontiers for personalized clinical medicine]. Tjumenskij medicinskij zhurnal. 2019;21(1):20-40. (in Ukrainian).

17. Brancaccio M., Patton A.P., Chesham J.E. et al. Astrocytes Control Circadian Timekeeping in the Suprachiasmatic Nucleus via Glutamatergic Signaling. Neuron. 2017;93(6):1420-1435. doi: 10.1016/j. neuron.2017.02.030.

18. Douma L.G., Gumz M.L. Circadian clock-mediated regulation of blood pressure. Free Radic Biol Med. 2018;119:108-114. doi: 10.1016/j. freeradbiomed.2017.11.024

19. Jobanputra A.M., Scharf M.T., Androulakis I.P. et al. Circadian Disruption in Critical IIIness. Front Neurol. 2020;11:820. doi: 10.3389/ fneur.2020.00820.

20. Sun L., Ma J., Turck C.W. et al. Genome-wide circadian regulation: A unique system for computational biology. Comput Struct Biotechnol J. 2020;18:1914-1924. doi: 10.1016/j.csbj.2020.07.002.

21. Parkar S.G., Kalsbeek A., Cheeseman J.F. Potential Role for the Gut Microbiota in Modulating Host Circadian Rhythms and Metabolic Health. Microorganisms. 2019;7 (2):41. doi:10.3390/microorganisms7020041.

22. Woelders T., Beersma D., Gordijn M. et al. Daily Light Exposure Patterns Reveal Phase and Period of the Human Circadian Clock. J. Biol. Rhythms. 2017;32(3):274-286.

23. Zenina 0.Ju., Makarova I.I., Ignatova Ju.P. et al. Hronofiziologija i hronopatologija serdechno-sosudistoj sistemy (obzor literatury) [Chronophysiology and chronopathology of cardiovascular system (Literature Review). Jekologija cheloveka. 2017;1:25-33. (in Ukrainian).

24. Albakova M.H., Albakova H.A., Ausheva F.H. Biologicheskie ritmy i perspektivi hronoterapii [Biological rhythms and perspectives of chronotherapy]. Arhivarius. 2016;3(7):116-122. (in Ukrainian).

25. Volobuev A.N., Pjatin V.F., Romanchuk N.P. Cirkadiannaja biofizika i hronomedicina [Circadianal biophysics and chronomedicine]. Zdorov'e i obrazovanie v XXI veke. 2016;5:97-100. (in Ukrainian).

26. Matsui M.S., Pelle E., Dong K. et al. Biological Rhythms in the Skin. Int. J. Mol. Sci. 2016;17(6):801.

27. Münch M., Kramer A. Timing matters: New tools for personalized chronomedicine and circadian health. Acta Physiologica. 2019;227(2):e13300. doi: 10.1111/apha.13300.

28. Kolbe I., Oster H. Chronodisruption, Metabolic Homeostasis, and the Regulation of Inflammation in Adipose Tissues. Yale J Biol Med. 2019;92(2):317-325.

29. Tamai T.K., Nakane Y., Ota W. et al. Identification of circadian clock modulators from existing drugs. EMBO Mol Med. 2018;10(5):e8724. doi: 10.15252/emmm.201708724. 
30. Touitou Y., Reinberg A., Touitou D. Association between light at night, melatonin secretion, sleep deprivation, and the internal clock: Health impacts and mechanisms of circadian disruption. Life Sci. 2017;173:94106. doi: 10.1016/j.Ifs.2017.02.008.

31. Chaulin A.M., Dupljakova P.D., Dupljakov D.V. Cirkadnye ritmy serdechnyh troponinov: mehanizmy i klinicheskoe znachenie [Circadian rhythms of cardiac troponins: mechanisms and clinical significance]. Rossijskij kardiologicheskij zhurnal. 2020;25(S3):62-69. doi:10.15829/15604071-2020-4061(in Ukrainian).

32. Zaguskin S.L., Verigin S.V. Personalizirovannaja profilakticheskaja hronomedicina: integracija podhodov zapadnoj i vostochnoj mediciny [Personalised preventive chronomedicine: integration of Western and Eastern medicine approaches]. Prostranstvo iVremja. 2017;1(27):234246. (in Ukrainian).

33. Skene D.J., Skornyakov E., Chowdhury N.R. et al. Separation of circadianand behavior-driven metabolite rhythms in humans provides a window on peripheral oscillators and metabolism. Proc Natl Acad Sci USA. 2018;115(30):7825-7830. doi:10.1073/pnas.1801183115.

34. Smolensky M.H., Reinberg A.E., Fischer F.M. Working Time Society consensus statements: Circadian time structure impacts vulnerability to xenobiotics-relevance to industrial toxicology and nonstandard work schedules. Ind Health. 2019;57(2):158-174. doi:10.2486/indhealth. SW-2.

35. Masri S., Sassone-Corsi P. The emerging link between cancer, metabolism, and circadian rhythms. Nat Med. 2018;24(12):1795-1803. doi:10.1038/s41591-018-0271-8.

36. van den Berg R., Noordam R., Kooijman S. et al. Familial longevity is characterized by high circadian rhythmicity of serum cholesterol in healthy elderly individuals. Aging Cell. 2017;16(2):237-243. doi:10.1111/acel.12547.

37. Winter C., Silvestre-Roig C., Ortega-Gomez A. et al. Chronopharmacological Targeting of the CCL2-CCR2 Axis Ameliorates Atherosclerosis. Cell Metab. 2018;28(1):175-182. doi: 10.1016/j. cmet.2018.05.002.

38. Panda S. The arrival of circadian medicine. Nat Rev Endocrinol. 2019;15(2):67-69. doi: 10.1038/s41574-018- 0142-x.

39. Singh R.K., Singh R., Singh V. et al. View Point: Chronomedicine. A Boon for Emerging Diseases. Nova Science Publishers, Inc. World Heart Journal. 2016;8(1):65-69.

40. Ashok Kumar P.V., Dakup P.P., Sarkar S. et al. It's About Time: Advances in Understanding the Circadian Regulation of DNA Damage and Repair in Carcinogenesis and Cancer Treatment Outcomes. Yale J Biol Med. 2019;92(2):305-316.

41. Crnko S., Du Pré B.C., Sluijter J.P.G. et al. Circadian rhythms and the molecular clock in cardiovascular biology and disease. Nat Rev Cardiol. 2019;16(7):437-447. doi: 10.1038/s41569-019-0167-4.

42. Gubin D.G., Weinert D., Rybina S.V. et al. Activity, Sleep and Ambient Light Have a Different Impact on Circadian Blood Pressure, Heart Rate and Body Temperature Rhythms. Chronobiology Int. 2017;34(5):632649. doi: 10.1080/07420528.2017.1288632.

43. Hermida R.C., Ayala D.E., Fernández J.R. et al. Hypertension: New perspective on its definition and clinical management by bedtime therapy substantially reduces cardiovascular disease risk. Eur J Clin Invest. 2018;48(5):e12909. doi: 10.1111/eci.12909.

44. Bhattacharjee S., Haldar P., Gopal Maity S. et al. Prevalence and Risk Factors of Asthma and Allergy-Related Diseases among Adolescents (PERFORMANCE) study: rationale and methods. ERJ Open Res. 2018;4(2):00034-2018. doi:10.1183/23120541.00034-2018.
45. Jakubowicz D., Wainstein J., Landau Z. et al. Influences of Breakfast on Clock Gene Expression and Postprandial Glycemia in Healthy Individuals and Individuals With Diabetes: A Randomized Clinical Trial. Diabetes Care. 2017;40(11):1573-1579. doi: 10.2337/dc16-2753.

46. Poggiogalle E., Jamshed H., Peterson C.M. Circadian regulation of glucose, lipid, and energy metabolism in humans. Metabolism. 2018;84:11-27. doi: 10.1016/j.metabol.2017.11.017.

47. Mason I.C., Qian J., Adler G.K. et al. Impact of circadian disruption on glucose metabolism: implications for type 2 diabetes. Diabetologia. 2020;63:462-472.

48. Juj R.I., Ergazina M.Zh. Razrabotka sposoba preventivnoj hronoterapii gingivitov i parodontitov [Elaboration of the method of preventive gingivitis and parodentitis chronotherapy]. Vestnik KyrgyzskoRossijskogo Slavjanskogo universiteta. 2020;20(9):138-141. (in Ukrainian).

The article is a fragment of the initiative research topic «Differential approach to the treatment methods choice depending on morphofunctional features of teeth hard tissues and oral cavity tissues" state registration № 0115 U01112 and state order research topic "Contribution of the molecular clock components impact to periodontal tissues affection during inflammatory diseases for the development of prevention and treatment methods" state registration № $0120 U 104124$.

\section{ORCID and contributionship:}

Maryna Y. Vasko: 0000-0003-2164-7076 ${ }^{B, D}$

Iryna M. Tkachenko: 0000-0001-8243-8644 A, D, F

Olena V. Pavlenkova: 0000-0002-3106-123 C, F

Oleg A. Pysarenko: 0000-0002-6104-6745 E, F

\section{Conflict of interest:}

The Authors declare no conflict of interest.

\section{CORRESPONDING AUTHOR Maryna Y. Vasko \\ Poltava state medical university \\ 23 Shevchenko st., 36000 Poltava, Ukraine \\ tel: +380991588566 \\ e-mail: vaskomarina331@gmail.com}

Received: 11.04.2021

Accepted: 30.07 .2021
A - Work concept and design, B - Data collection and analysis, C - Responsibility for statistical analysis, D -Writing the article, $\mathbf{E}$-Critical review, $\mathbf{F}$ - Final approval of the article 